\title{
MARTYRIA SEBAGAI WUJUD KEBEBASAN MORAL
}

\author{
Lesta Sembiring* \\ Fakultas Filsafat Universitas Katolik Santo Thomas \\ Email : lesta_sembiring@ust.ac.id
}

\begin{abstract}
Abstraksi
Kebebasan adalah lambang yang unggul citra ilahi dalam diri manusia (GS 17). Dengan kebebasannya manusia diarahkan kepada Allah untuk mencapai kesempurnaan dan kebahagian abadi, karena ia dilengkapi akal budi dan kehendak (KGK 1711), untuk mencari/mencintai kebenaran dan kebaikan (GS 15,2). Mencari/mencintai kebenaran dan kebaikan sudah merupakan kewajiban dan tanggungjawab orang kristen (optio fundamentalis), sebab ia harus tumbuh dan matang di dalamnya (KGK 1731), serta memberi kesaksian (martyria) tentang kebenaran dan kebaikan itu (minimal dalam optio particularis).
\end{abstract}

Kata Kunci: kebebasan, martyria, kebenaran, kebaikan, suara hati, optio fundametalis, optio particularis, kewajiban, tanggung jawab.

\section{Kebebasan}

Kebebasan adalah salah satu ciri khas manusia dan merupakan anugerah yang luar biasa dari Tuhan. Anugerah ini sangat meninggikan martabat manusia, karena berupa kemampuan untuk mengarahkan hidupnya kepada kesempurnaan. ${ }^{1}$ Dari segi etimologi, istilah kebebasan berasal dari kata "bebas" (kata sifat) yang berarti merdeka, tidak terikat

*Lesta Sembiring, lisensiat dalam bidang Teologi Moral lulusan Alfonsiana-Roma; dosen Teologi Moral pada Fakultas Filsafat Universitas Katolik Santo Thomas Sumatera Utara.

${ }^{1}$ Francesco Compagnoni, Giannino Piana, salvatore Privitera (a cura di), Nuova Dizionario di Teologia Morale, (Milano: Edizione San Paolo, 1990), hlm. 658-662. Manusia di dunia memiliki peranan membangun kehidupannya. Aktualisasi diri, selalu dilakukan dari sebuah kesadaran akan kemampuannya untuk membangun lingkungan di sekitarnya. Pada kondisi seperti itu, manusia akan mewujudkan peranannya dalam perbuatan-perbuatan atau tindakan untuk menyempurnakan hidupnya dengan akal budi dan kehendak 
oleh aturan. Dalam kamus besar Bahasa Indonesia kata "bebas" mempunyai arti tidak terhalang, tidak terganggu, sehingga dapat bergerak, berbicara, bertindak. Kata bebas menggambarkan pada suatu kondisi yang memungkinkan seseorang untuk bertindak lepas dari kewajiban, tuntutan, perasaan takut, sehingga dapat melakukan tindakannya dengan murni dari dirinya sendiri. ${ }^{2}$

Dalam filsafat pengertian kebebasan dipahami sebagai kemampuan manusia untuk menentukan dirinya sendiri. Kebebasan ini merupakan potensi untuk berpikir, berkehendak dan bertindak tanpa paksaan. Kebebasan tidak dimengerti hanya sebagai sebuah situasi atau suasana dimana manusia dengan leluasa melakukan sesuatu, tetapi dipahami sebagai sebuah kemampuan. ${ }^{3}$ Kemampuan ini mengungkapkan martabatnya sebagai manusia, sehingga ia dapat dibebani kewajiban dan tanggungjawab moral. ${ }^{4}$

\section{Jenis-jenis Kebebasan}

Berbicara tentang kebebasan harus dibedakan beberapa pengertian kebebasan:

Pertama, kebebasan eksistensial: kebebasan dalam arti kemampuan manusia untuk menentukan tindakannya sendiri. Sifat kebebasan ini positif karena tidak menekankan bebas dari apa, melainkan bebas untuk apa. Melalui kebebasan eksistensialnya, manusia sanggup menentukan tindakannya sendiri. Tindakan di sini, dapat diartikan sebagai kegiatan yang disengaja, dilakukan dengan maksud dan tujuan tertentu, dengan kesadaran tergantung penuh pada diri kita sendiri. ${ }^{5}$

\footnotetext{
2Departemen Pendidikan Nasional, Kamus Besar Bahasa Indonesia Pusat Bahasa (edisi keempat), (Jakarta : Penerbit PT Gramedia Pustaka Utama, 2012) , hlm. 153-154.

${ }^{3}$ Kemampuan sudah ada dalam diri manusia secara hakiki, sehingga dapat berbuat baik atau merealisasikan dirinya menjadi orang yang baik. Berbuat baik merupakan tanggung jawab dan tugas manusia yang pokok dan utama. Melalui kebebasannya manusia diarahkan untuk berbuat baik dan menghindarkan yang buruk (dengan mengikuti suara hati).

4Franz Magnis-Suseno, ETIKA DASAR Masalah-masalah Pokok Filsafat Moral, (Yogyakarta: Penerbit Kanisius, 1987), hlm. 21-22.

5 Kebebasan eksistensial berakar dalam kebebasan rohani manusia, yaitu dalam penguasaan manusia terhadap batinnya, terhadap pikiran dan kehendaknya. Kebebasan eksistensial terungkap dan mencapai realitasnya dalam tindakan yang berakar dalam kebebasan batin, tetapi terwujud dalam dimensi lahiriah. Kebebasan eksistensial
} 
Kebebasan eksistensial menyangkut seluruh pribadi manusia dan tidak terbatas pada salah satu aspek saja. Kebebasan ekstensial merupakan kebebasan tertinggi karena mengarah pada suatu cita-cita yang bisa memberi arah dan makna kepada kehidupan manusia. ${ }^{6}$

Kedua, kebebasan sosial: kebebasan ini dihayati dalam hubungannya dengan orang lain atau kebebasan yang diterima dari orang lain (bebas dari apa). ${ }^{7}$ Kebebasan ini dipahami sebagai realitas negatif artinya, dimana kemungkinan kita untuk menentukan tindakan kita sendiri tidak dibatasi oleh orang lain. Seseorang bebas dalam arti sosial, apabila ia tidak berada di bawah paksaan, tekanan, atau kewajiban dan larangan dari pihak lain. ${ }^{8}$

Ketiga, kebebasan moral: kebebasan ini berbicara mengenai kewajiban dan tanggungjawab manusia. Kewajiban dan tanggungjawab itu diaplikasikan dalam peran, status, profesi, posisi, manusia yang hidup dengan manusia lain. ${ }^{9}$ Kebebasan moral diaktualisasikan dalam prilaku individu yang berhubungan langsung dengan kewajiban ${ }^{10}$ dan tanggungjawabnya ${ }^{11}$.

berhubungan erat dengan kebebasan jasmani, yaitu kemampuan manusia untuk menentukan gerakan tubuhnya sebagai ungkapan kehendaknya yang bebas.

6Franz Magnis-Suseno, ETIKA DASAR..., hlm. 23-25.

${ }^{7}$ Kebebasan sosial berhubungan dengan kehendak orang lain yang mengancam kebebasan kita. Pembatatasan ini melalui: 1) Paksaan (kebebasan jasmani) dengan memakai kekuatan fisik untuk membuat kita tidak berdaya, agar tidak mampun bergerak atau bertindak; 2) Tekanan (psikis), menyangkut kekuasaan manusia terhadap batinnya. Tekanan membuat manusia kurang dapat berfikir dan tidak bebas mengarahkan kehendaknya. Tekanan psikis dapat dilakukan dengan informasi-informasi, sugesti, hipnotis, siksaan fisik dan manipulasi secara emosional yang mengganggu pikiran manusia; 3) Melalui kewajiban, perintah dan larangan (kebebasan normatif). ${ }^{8}$ Franz Magnis-Suseno, ETIKA DASAR..., hlm. 26-29. hlm. 96-97.

${ }^{9}$ Bdk. Guido Gatti, Manuale di Teologia Morale, (Leumann-Torino: Editrice Elledice, 2001),

${ }^{10}$ Sebagai contoh, seorang frater makan mei pangsit di Restoran AWAI, harga mei pangsit Rp 15.000 per porsi, setelah makan mei pangsit, frater tersebut membayar pangsitnya dengan uang Rp 50.000, kemudian penjual pangsit memberikan uang kembaliannya Rp 85.000,- Bagaimanakah sikap Frater tersebut? Tindakan apakah yang harus dibuat? Apakah ia mengembalikan kelebihan atau tidak? Seharusnya dia berkewajiban mengembalikan kelebihan uang itu. Tetapi bisa saja terjadi opsi/putusan lain. Maka dalam kasus/situasi seperti ini, kebebasan moral seseorang sungguh berperan dan ditantang.

${ }^{11}$ Contoh lain yakni, seorang ayah/ibu mempunyai tanggung jawab moral untuk membesarkan anak-anaknya. Pada titik ini kebebasan eksistensil bukan dibatasi oleh kondisi atau situasi, namun pikiran dan suara hati akan menuntun dia untuk melaksanakan tanggungjawabnya. Bisa saja seorang bapak/ibu menggabaikan tanggung jawabnya ( menelantarkan anaknya). Bila demikian terjadi, bapak/ibu akan memiliki beban moral, dan apabila ada hukum yang mengatur hal tersebut, bapak/ibu tersebut akan menghadapi masalah hukum. Beranjak dari kasus ini, tanggungjawab seringkali menimbulkan beban moral dan menyebabkan problem moral dalam diri individu (menimbulkan stress dan penyakit). Tak jarang tanggungjawab yang tidak dijalankan akan menimbulkan problem moral yang bisa berlaku kolektif dan menjadi problem moralitas. 
Manusia yang memiliki kebebasan moral adalah manusia normal dalam arti, manusia yang tidak mempunyai hambatan fisik atau psikis misalnya mental retarded atau stroke, sehingga mampu mengimplementasikan atau mengekspresikan dirinya dalam berbagai tindakan. Tindakan ini merupakan pengejawantahan dari kebebasan moral seseorang berdasarkan tuntunan suara hati dengan pergulatan analisa rasional dan kondisional. ${ }^{12}$ Kebebasan moral berbicara mengenai kemampuan manusia untuk menerima perintah suara hati (pergulatan kebebasan eksistensial dan sosial). Dalam pergulatan dan perbenturan ini, suara hati akan suara memberikan jawaban dan keputusan untuk berprilaku (action) dengan tepat dan benar. ${ }^{13}$

\section{Fungsi Kebebasan}

Kebebasan moral berfungsi untuk memupuk kesadaran moral manusia. Seseorang yang memiliki kebebasan akan melihat setiap kewajiban moral sebagai sesuatu yang sangat berguna bagi dirinya dan dikehendaki untuk dilakukan. Mentaati kewajiban berarti mentaati dirinya sendiri. Mentaati kewajiban moral, secara otonom sedikitpun tidak merendahkan martabat manusia, karena ia telah menghayati kebebasannya dengan penuh. Kebebasan moral sebagai kemampuan untuk menentukan diri sendiri, diaplikasikan dalam bentuk tindakan yang bebas. Melalui tindakan itu, manusia dapat mengenal identitas atau orang macam apakah dia sebenarnya. ${ }^{14}$

Kebebasan moral mempertebal dan meninggikan rasa tanggung jawab, karena bila tidak ada kebebasan, kemampuan untuk bertanggung jawab pun akan menyurut. Melakukan kewajiban tidak hanya disadari oleh sesuatu yang diwajibkan (harus dilakukan) melainkan dengan sadar bahwa saya melakukan itu demi suatu kebaikan yang mau dijamin oleh kewajiban itu. Dengan kata lain, sikap moral yang dewasa

${ }^{12}$ Bdk. Jean-Louis Brugues, Dizionario di Morale Cattolica, (Bologna: PDUL Edizione Studio Domenicano, 1991), hlm. 212-213.

13Jean-Louis Brugues, Dizionario di Morale Cattolica..., hlm. 214.

${ }^{14} \mathrm{Bdk}$. Francesco Compagnoni, Giannino Piana, salvatore Privitera (a cura di), Nuova Dizionario di Teologia Morale..., hlm. 662-666. 
adalah sikap yang bertanggung jawab untuk mencapai yang baik dan bernilai bagi dirinya sendiri dan orang lain (bonum comune). ${ }^{15}$

\section{Kebebasan Merupakan Lambang Citra Ilahi}

Allah menciptakan manusia sebagai makhluk yang berakal budi untuk bertindak seturut kehendaknya sendiri. Allah menyerahkan manusia kepada keputusannya sendiri (Sir 15:14), supaya ia dengan sukarela mencari Penciptanya dan mengabdi kepada-Nya secara bebas untuk mencapai kesempurnaan sepenuhnya demi kebahagiaannya. ${ }^{16}$ Manusia itu, berakal budi dan karena ia citra Allah, diciptakan dalam kebebasan, ia tuan atas tingkah lakunya. ${ }^{17}$ Melalui kebebasan moral, manusia memiliki kemampuan yang berakar dalam akal budi dan kehendak, mencari/mencapai serta tumbuh dan matang dalam kebenaran dan kebaikan. ${ }^{18}$

\section{Kebebasan Moral Mengarahkan Manusia Kepada Kebenaran dan Kebaikan}

Manusia diciptakan menurut gambar dan rupa (citra) Allah, memiliki akal budi dan kehendak agar sanggup mencari dan mencapai kebenaran. Kebebasan merupakan tanda istimewa dari manusia sebagai imago Dei, lambang unggul citra Ilahi di dalam manusia, agar manusia dengan bebas mentaati Hukum Tuhan yang tersirat dalam suara hatinya untuk mencari dan mencapai kebenaran. ${ }^{19}$ Sejak awal manusia dipanggil untuk bersatu dengan Allah, diundang untuk berdialog dengan-Nya, hidup sepenuhnya menurut kebaikan dan cinta kasih dengan bebas, dan dengan bebas pula menyerahkan diri kepada Penciptanya. Manusia diundang untuk berkembang dan sempurna dalam kebenaran dan kebaikan. ${ }^{20}$ Kepenuhan perkembangan dan kesempurnaan akan dapat dicapai melalui akal budi dan kehendaknya. Menurut prinsip: potentur specificatur ab obiecto, objek dari akal budi manusia adalah kebenaran (ens ut verum), sedangkan objek dari

${ }^{15}$ Bdk. Francesco Compagnoni, Giannino Piana, salvatore Privitera (a cura di), Nuova Dizionario di Teologia Morale..., hlm. 666-671.

${ }^{16}$ GS, no. 17

${ }^{17}$ Bdk. Bernard Haring, The Law of Christ: Moral Theology for Priests and Laity. Vol. III, (Cord: The Mercier Press, 1959), hlm. 271-272.

${ }^{18}$ KGK, no. 1731.

${ }^{19}$ Bdk. GS, no. 16

${ }^{20}$ Bdk. Bernard Haring, The Law of Christ..., hlm. 534-536. 
kehendak adalah kebaikan (ens ut bonum). Manusia yang diciptakan menurut citra Tuhan, dengan akal budi dan kehendak mampu untuk mencapai kesempurnaan dan kebahagiaan tertinggi, dengan tumbuh dan matang dalam kebenaran dan kebaikan.

\section{Kebenaran}

Dalam etimologi teologi, kebenaran memilki kata dasar dari benar. Kamus bahasa Indonesia memberikan beberapa pengertian tentang kebenaran, yaitu keadaan yang cocok dengan fakta, hal yang sebenarnya, atau sesuatu yang sungguh-sungguh benar-benar ada. ${ }^{21}$ Menurut bahasa Ibrani kebenaran disebut dengan kata tsadaq, sedangkan dalam bahasa Yunani disebut dikaioo, yang berarti mengumumkan suatu keputusan yang menyenangkan, atau menyatakan benar. Konsep ini tidak berarti menjadikan benar, tetapi menyatakan kebenaran. Menyatakan kebenaran merupakan konsep dalam persidangan, sehingga membenarkan berarti membubuhkan keputusan yang benar. Perbedaan antara membenarkan dengan menyatakan salah dapat dilihat dalam Ulangan 25:1 dan 1 Raja-raja 8:32 dan Amsal 17:15.22 Dalam bahasa Inggris kebenaran digunakan dengan kata true, yang berarti benar, betul, sebenarnya, setia, tulus, sesuai dengan kenyataan. Dalam kamus Indonesia-Inggris, Inggris-Indonesia, kata true diterjemahkan dengan kata sungguh, nyata, betul, memberikan tempat yang tepat, dan mencocokkan hingga tepat sekali.

Tuhan Yesus adalah Kebenaran itu, memang itulah fakta yang sebenarnya (sesuai dengan kenyataan). Tuhan Yesus adalah Kebenaran bagi mereka yang percaya kepada-Nya (Yoh. 14:6). Dosa manusia telah dibayar lunas di atas kayu salib dan hal itu dihitung sebagai suatu kebenaran (1 Kor. 6:20; 7:23). Hanya melalui Dia-lah manusia berdosa dibenarkan, bukan melalui amal dan kesalehannya sendiri (Kornelius

\footnotetext{
${ }^{21}$ Departemen Pendidikan Nasional. Kamus Besar Bahasa Indonesia Pusat Bahasa..., hlm. 167-168.

${ }^{22}$ Flavio Dalla Vecchia, Giuseppe Segalla, Marco Vironda (a cura di), Nuovo Grande Commentario Biblico (Edisizione Italiana), (Brescia: Editrice Queriniana, 1997), hlm. 436-438; Bdk. E. Beyruther, New International Dictionary of New Testament Teology 2, (Abridged Edition, 2000), hlm. 98-100.
} 
dalam Kisah Para Rasul 10). ${ }^{23}$ Manusia yang berdosa dibenarkan oleh Yesus Kristus (Rm. 3:20-26). Tuhan Yesus rela mati di kayu salib dan itu adalah kenyataan, "kematian terhadap dosa bukanlah sekedar harapan melainkan realita, sebab Kristus telah mati bagi dosa dan kita diikut sertakan dengan Dia dalam kematian-Nya." Inilah kebenaran yang diberitakan Yesus, Dia berkata: "Akulah kebenaran dan hidup (Yoh. $14: 6) \cdot{ }^{24}$

Orang Kristen hendaknya berusaha senantiasa mewujudnyatakan sikap hidup yang benar, baik dalam tutur kata maupun dalam tingkah laku. Sebab Kristus telah menyatakan kebenaran-Nya dalam perkataan dan perbuatan. Ia telah membenarkan hidup kita, sehingga kita beroleh kasih karunia dihadapan Tuhan. Sebagai anak Allah, kita harus memberitakan kebenaran yang telah tertulis dalam firman Tuhan kepada setiap umat manusia tanpa kecuali. 25

\section{Kebaikan}

Kebaikan sama sekali tidak mengandung sesuatu yang buruk atau busuk, sifatnya positif, dan diwujudkan dalam perbuatan dan tindakan baik, yang menguntungkan orang lain. ${ }^{26}$ Dalam Kitab Suci, kata paling umum untuk "baik" adalah kata Ibrani טוב - "TOV" (tohv) artinya, "menyenangkan", "menggembirakan", "ramah", menandakan sesuatu yang memberi kebahagiaan (tindakan moral). Septuaginta (LXX) menerjemahkan טוב - "TOV" dengan "ajaӨos - agathos", untuk menerangkan gagasan yang "baik" sebagai kualitas/pengertian moral

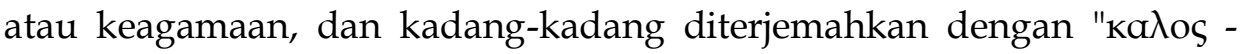
kalos" secara harfiah diartikan dengan, "cantik".27 Jadi baik dalam bahasa Yunani klasik maupun dalam Kitab Suci, "baik" mengarah pada

${ }^{23} \mathrm{E}$. Beyruther, New International Dictionary of New Testament Teology 2..., hlm. 101-104.

${ }^{24}$ E.Beyruther, New International Dictionary of New Testament Teology 2..., hlm. 105-107; Bdk. Guido Gatti, Manuale di Teologia Morale..., hlm. 97-98.

${ }^{25}$ Bdk. Guido Gatti, Manuale di Teologia Morale..., hlm. 98-99.

${ }^{26}$ KGK no. 1733. Bdk. Tullo Goffi-Giannino edd), Corso di Morale, (Brescia: Editrice Queriniana, 1989), hlm. 373-387.

${ }^{27}$ Carl Ferdinand Howard Henry, Christian Personal Ethics (Grand Rapids: William B. Eerdmans, 1957), hlm. 209-2014. 
arti, "mulia", "yang terhormat", "mengagumkan", "patut". Perjanjian Baru mengembangkan pemakaian kata "baik" dengan menggunakan kedua

kata sifat di atas (agathos dan kalos) secara bergantian (Roma 7:12-21). ${ }^{28}$ Dalam pengertian Alkitabiah, kebaikan (moral/spiritual) adalah benarbenar teologis, karena mengarahkan pengertian kebaikan (baik) itu kepada Allah. Pengertian dan pengarahan itu diuraikan sebagai berikut:

\section{a. Allah adalah Baik}

Secara moral Allah adalah sempurna, maha agung dan murah hati. Pengakuan bahwa Ia baik, merupakan alasan dasar dari semua pemikiran Alkitabiah tentang kebaikan. Dalam Kitab Suci "baik" bukanlah kualitas abstrak, bukan juga cita-cita manusia sekuler. "Baik" pertama-tama dan terutama mengarah kepada pengertian apa atau siapakah Allah itu ("Ia adalah baik": Mzm 100:5; Mzm 25:8; Za 9:17,

${ }^{28}$ Flavio Dalla Vecchia, Giuseppe Segalla, Marco Vironda (a cura di), Nuovo Grande Commentario Biblico..., hlm. 1113-1114; Carl Ferdinand Howard Henry, Christian Personal Ethics..., hlm. 2015-2018. Dengan penjelasan ayat 7:12, Jadi hukum Taurat adalah kudus, dan perintah itu juga adalah kudus, benar dan baik (AGATHOS); 7:13, Jika demikian, adakah yang baik itu menjadi kematian bagiku? Sekali-kali tidak! Tetapi supaya nyata, bahwa ia adalah dosa, maka dosa mempergunakan yang baik (AGATHOS) untuk mendatangkan kematian bagiku, supaya oleh perintah itu dosa lebih nyata lagi keadaannya sebagai dosa. 7:14, Sebab kita tahu, bahwa hukum Taurat adalah rohani, tetapi aku bersifat daging, terjual di bawah kuasa dosa. 7:15, Sebab apa yang aku perbuat, aku tidak tahu. Karena bukan apa yang aku kehendaki yang aku perbuat, tetapi apa yang aku benci, itulah yang aku perbuat. 7:16, Jadi jika aku perbuat apa yang tidak aku kehendaki, aku menyetujui, bahwa hukum Taurat itu baik (KALOS). 7:17, Kalau demikian bukan aku lagi yang memperbuatnya, tetapi dosa yang ada di dalam aku. 7:18, Sebab aku tahu, bahwa di dalam aku, yaitu di dalam aku sebagai manusia, tidak ada sesuatu yang baik (AGATHOS). Sebab kehendak memang ada di dalam aku, tetapi bukan hal berbuat apa yang baik (KALOS). 7:19, Sebab bukan apa yang aku kehendaki, yaitu yang baik (AGATHOS), yang aku perbuat, melainkan apa yang tidak aku kehendaki, yaitu yang jahat, yang aku perbuat. 7:20, Jadi , jika aku berbuat apa yang tidak aku kehendaki, maka bukan lagi aku yang memperbuatnya, tetapi dosa yang diam di dalam aku. 7:21, Demikianlah aku dapati hukum ini: jika aku menghendaki berbuat apa yang baik (KALOS), yang jahat itu ada padaku. 
dsb), kemudian, apa yang Ia buat, ciptakan, perintahkan, dan berikan. Akhirnya, apa yang Ia terima sebagai baik dalam kehidupan makhlukmakhluk-Nya. ${ }^{29}$ Para penulis Kitab Suci menilai Allah dalam rangka dan pengertian "baik" berdasarkan penalaran atas kesempurnaan kemuliaan Allah Yang Maha tinggi. Mereka mengartikan kata "baik" dalam arti yang baru, dengan menilai 'baik' menurut Allah; bukan sebaliknya. Jadi, Kitab Suci mengarahkan kebaikan kepada Allah, Dia sendiri yang adalah baik tanpa keterangan lain. Yesus Kristus tidak mau menerima gelar "Baik", dan mengatakan kepada orang yang menyebut-Nya sebagai "Guru Yang Baik". Lalu Yesus menolaknya, "Mengapa engkau menyebut Aku baik? Tidak seorang pun yang baik, kecuali satu, yakni Allah" (Mrk 10:17, 18). Dengan demikian, Yesus pun mengakui bahwa Allah-lah standar tertinggi untuk apa yang baik. ${ }^{30}$

\section{b. Perbuatan-Perbuatan Allah adalah Baik}

Perbuatan-perbuatan Allah menyatakan sifat-sifat kebijaksanaan dan kuasa-Nya (Mzm 104:24-31). Ketika perbuatan penciptaan selesai, "Allah melihat segala yang dijadikan-Nya itu, sungguh amat baik" (Kej 1:31; ay $4,10,12,18,21,25)$. Seluruh alam semesta sebagai hasil karya Allah adalah baik (1 Tim 4:4; Rm 14:14). ${ }^{31}$

\section{c. Pemberian-Pemberian Allah adalah Baik}

Pemberian-pemberian Allah mengungkapkan kemurahan hatiNya, dan diuntukkan bagi kesejahteraan dan keselamatan si penerima. Pemberian Allah adalah baik dan tujuan maupun dampak-dampaknya. Segala yang baik pada hakikatnya adalah pemberian Allah (Yak 1:17; bnd Mzm 4:6). Ciri khas Allah adalah berbuat baik (Mrk 3:4; Kis 10:38). Allah berbuat baik bagi semua orang (Mzm 145:9; Luk 6:35; Kis 14:17); dan sebagai Bapak yang sempurna, Ia tahu bagaimana memberikan pemberian-pemberian yang baik (Mat 7:11). ${ }^{32}$

${ }^{29}$ B. B. Warfield, The Person and Work of Christ, 1950, hlm 147-148.

${ }^{30}$ B. B. Warfield, The Person and Work of Christ, 1950, hlm 149-150.

${ }^{31}$ Flavio Dalla Vecchia, Giuseppe Segalla, Marco Vironda (a cura di), Nuovo Grande Commentario Biblico..., hlm. 1171.

32 Flavio Dalla Vecchia, Giuseppe Segalla, Marco Vironda (a cura di), Nuovo Grande Commentario

Biblico..., hlm. 785-786. 
Ia berjanji "berbuat baik" kepada umat-Nya dengan berkat-berkat yang berlipat ganda (Yer 32:40; bnd 24:6 dsb; Mzm 51:18; 125:4; Yes 52:7; U1 30:15; Ibr 9:11; 10:1). Perjanjian itu mensahkan umat-Nya agar tetap setia, percaya, dan pada waktu yang telah ditetapkan Allah, segala sesuatu yang "baik" akan menjadi milik mereka (Mzm 84:11; 34:10; bnd Mzm 85:12; Rm 8:32; Ef 1:3). "Baik" sebagai kata sifat, dipakai dalam berbagai pengertian berkaitan dengan tindakan-tindakan Allah (anugerah), dalam melakukan hal yang 'baik' bagi manusia.

\section{d. Ketaatan Kepada Perintah-Perintah Allah adalah Baik}

Allah berkenan dan menerima umat/orang yang taat (1 Tim 2:3), dan mereka yang melakukan ketaatan itu akan memperoleh keuntungan (Tit 3:8). Orang-orang yang tidak diselamatkan dari dosa dan tidak menaati hukum-hukum Allah, mereka berada di dalam belenggu "di bawah kuasa dosa" (Rm 3:9 dab; 8:7 dsb). Pohon yang tidak baik (manusia dalam Adam) harus dijadikan baik sebelum ia dapat menghasilkan buah yang baik (Mat 12:33-35). Tetapi mereka yang berada dalam Kristus telah dibebaskan dari belenggu dosa, justru supaya mereka dapat menerapkan kebenaran yang ditetapkan oleh hukum (Rm 6:12-22). Perjanjian Baru mewajibkan orang Kristen melakukan ketaatan dengan sebutan "pekerjaan yang baik" atau melakukan kebaikan. ${ }^{33}$

Orang Kristen diperintahkan untuk mencari, menyimpulkan apa kebaikan Allah itu dan apa kehendak-Nya yang sempurna bagi mereka ( $\operatorname{Rm} 12: 2) ;$ mereka harus berpaut pada apa yang baik ( $\operatorname{Rm} 12: 9)$, melakukannya (Rm 2:10;13:3), mengejarnya (1Tes 5:15), bergairah untuknya (1Ptr 3:13), meniru yang baik (3Yoh 11), dan menaklukkan apa yang jahat dengan apa yang baik (Rm 12:21). Mereka berbuat baik

\footnotetext{
${ }^{33}$ Kebaikan dihasilkan dari ketaatan kepada perintah Allah; tidak seorang pun memiliki kebaikan karena upayanya sendiri (Rm 7:18). Sang pemazmur memohon kepada Allah sebagai Sumber kebaikan, "Ajarlah aku kebaikan, akal sehat dan pengetahuan, karena aku memperlihatkan iman akan perintah-perintahmu," dan, "Engkau baik dan berbuat baik. Ajarlah aku peraturan-peraturanmu." (Mz 119:66, 68).
} 
(melakukan kebaikan), teristimewa kepada saudara-saudara mereka dalam iman Kristen, dan juga kepada semua orang lain (Gal 6:10). ${ }^{34}$

\section{Martyria Sebagai Wujud Kewajiban dan Tanggung Jawab Moral}

Melalui kebebasan moralnya, orang Kristen tidak hanya berpuas diri dalam hal tumbuh/matang dalam kebenaran dan kebaikan saja, tetapi secara moral ia memiliki kewajiban dan tanggung jawab untuk mengaplikasikan atau melaksanakannya dalam hidup konkrit. ${ }^{35}$ Aplikasi/tuntutan kewajiban dan tanggung jawab ini dapat diwujudkan dengan:

\section{Mengerjakan Perbuatan-Perbuatan Baik}

Melakukan pekerjaan-pekerjaan yang baik haruslah menjadi kewajiban orang Kristen sepanjang hidupnya; karena untuk itulah Allah telah menyelamatkan dia (Mat 5:14-16; 2 Kor 9:8; Ef 2:10; Kol 1:10; Tit 2:14). Orang Kristen dipanggil untuk siap sedia mengerjakan setiap pekerjaan yang baik (2 Tim 2:21; Tit 3:1), sehingga celakalah orang yang mengaku dirinya Kristen tetapi "tidak sanggup berbuat sesuatu yang baik" (Tit 1:6; Yak 2:14-26). Pekerjaan-pekerjaan yang baik adalah perhiasan atau dandanan orang Kristen (1 Tim 2:10). Allah berkenan atas perbuatan-perbuatan tersebut, dan mereka akan menerima pengindahannya dari Tuhan (Ef 6:8).

Pekerjaan-pekerjaan yang baik dilihat atau dilakukan: dari tiga sudut: (i) menurut patokan yang benar (hukum yang tertera dalam Kitab Suci; 2 Tim 3:16 dsb); (ii) berdasarkan alasan (motif) yang benar (kasih dan ucapan syukur atas keselamatan: 1 Tes 1:3; Ibr 6:10; bdk. Rm 12:1 dst); (iii) dengan tujuan yang benar (bagi kemuliaan Allah; 1 Kor

${ }^{34}$ Bdk. KGK, no. 1741.

${ }^{35}$ Bdk. KGK, no. 1731, 1738. 
10:31; bdk. Mat 5:6; 1 Kor 6:20; 1 Ptr 2:12). ${ }^{36}$ Pekerjaan-pekerjaan itu berupa perbuatan-perbuatan kasih terhadap Allah dan sesama manusia, karena "kasih adalah kegenapan hukum Taurat" (Rm 13:8-10; Mat 22:3640). Orang yang sungguh-sungguh baik adalah orang yang benar; sebab orang itu benar karena melaksanakan makna yang tersirat dan tersurat dalam perintah-perintah Tuhan (Mat 5:18-20). Jadi kategori orang baik itu, dihubungkan dengan melaksanakan yang tersurat bukan hanya "mengasihi".

Orang Kristen wajib berbuat baik dengan memberikan hal-hal yang bermanfaat bagi orang lain, sebab Allah ingin menyatakan kebaikan kepada umat-Nya. Sebagaimana doa Paulus bagi umat di Tesalonika, "Kami selalu berdoa bagimu, agar Allah kita menganggap kamu layak bagi panggilannya dan dengan kuasanya melaksanakan selengkapnya semua hal baik yang ia kehendaki dan pekerjaan iman." (2Tes 1:11). Ada banyak contoh tentang berlimpahnya kebaikan Allah terhadap orang-orang yang berpaling kepada-Nya (1Raj 8:66; Mz 31:19; Yes 63:7; Yer 31:12, 14). "Allah itu baik kepada semua orang, dan penuh rahmat terhadap segala karyanya" (Mz 145:9). Ia mengulurkan kebaikan kepada semua orang dengan suatu tujuan, agar kebaikan-Nya mendorong banyak orang untuk melayani Dia, dan memperlihatkan kebaikan itu, sehingga menjadi berkat bagi orang lain (Ams 11:10).

\section{Bersaksi (Martyria)}

Istilah "bersaksi" berasal dari kata "saksi", kata ini dipinjam dari dunia pengadilan. Saksi ialah orang yang lebih dahulu melihat sesuatu dan meminta orang lain agar melihat apa yang dilihatnya. Itulah saksi yang benar. Istilah "kesaksian" (marturia) adalah terjemahan dari "marturein", bahasa Yunani. Dari kata inilah muncul kata "martyr", yaitu orang yang mati syahid. Istilah marturein berhubungan dengan "kerussein" yaitu pemberitaan. Dari kata "kerussein" lahirlah kata "kerygma" yang artinya berita. "Marturein" berhubungan dengan "euanggelisesthai", pemberitaan kabar gembira dan "euanggelion", kabar gembira karena kedatangan Mesias atau Injil. Dalam bahasa Indonesia

${ }^{36}$ Bdk. KGK, no. 1750-1754, Sifat kesusilaan dari manusia bergantung pada: obyek yang dipilih, tujuan dan maksud yang dicapai, situasi dan kondisi perbuatan. 
istilah "evangelisasi", diartikan sebagai penginjilan. ${ }^{37}$ Dalam kerajaan Romawi sering ada pembawa berita kemenangan perang karena suatu wilayah telah ditaklukkan atau berita suka cita lainnya. Utusan yang berkeliling dengan tugas kerajaan ini disebut bentara. Pengertian itu kemudian "dikristenkan", dalam pewartaan Kerajaan Allah atau Injil yang merupakan inti berita/kerygma. Pemberitaan Injil diartikan sebagai kesaksian, sedangkan pemberita Injil adalah saksi, penginjil, bentara. ${ }^{38}$

Sejak zaman Perjanjian Lama, Roh Allah, yang adalah Allah sendiri, telah berada dan bekerja di dunia. Kehadiran Allah dirasakan dalam tindakan mengeluarkan Israel dari Mesir, Dalam Perjanjian Baru, Roh Allah itu sebut Roh Kudus. Ketika Yesus dibaptis, Roh itu turun ke dunia (Mrk. 1:9-11). Sejak peristiwa Pentakosta, Roh Kudus telah menumbuhkan gereja yang pertama (Kis. 2:1-13). Roh itu juga telah menggerakkan Paulus memberitakan Injil ke banyak negara. Selanjutnya Ia memimpin semua orang percaya untuk bersaksi tentang Yesus Kristus (kebenaran Allah), untuk menyongsong Kerajaan Allah yang akan terjadi dengan kedatangan Kristus yang kedua kelak. ${ }^{39}$

Tugas bersaksi dan kesaksian dari gereja-gereja adalah kesinambungan tugas rasuli. Bersaksi ialah menyaksikan Yesus Kristus (Sang Kebenaran) baik secara lisan, tulisan dan melalui perbuatan baik mereka, orang-orang lain mengenal bahwa Kristus itulah Juruselamat yang dicari orang sepanjang sejarah. Sasaran kesaksian ini ke dalam lingkungan warga gereja dan ke luar (masyarakat). Baik ke dalam maupun ke luar, kesaksian dimaksudkan untuk membawa orang-orang lain mengenal Kristus. Orang Kristen yang benar itu akan selalu bersaksi dengan segala cara dengan perbuatan baiknya (mencerminkan kebaikan Allah), dan tidak ada kekuatan apapun yang dapat membungkamnya.

\footnotetext{
${ }^{37}$ Angelo Di Berardino (diretto da), Dizionario Patristico e Diantichita Cristiane, (Casale Monferrato: Casa Editrice Marietti, 1983), hlm. 2133-2148.

38 Bdk. Angelo Di Berardino (diretto da), Dizionario Patristico e Diantichita Cristiane..., hlm. 2149-2151.

39 Bdk. Angelo Di Berardino (diretto da), Dizionario Patristico e Diantichita Cristiane..., hlm. 2152-2155.
} 
Lesta Sembiring, Martyria Sebagai Wujud Kebebasan Moral

\section{Mendengarkan Suara Hati}

Dalam mengambil keputusan, manusia mempunyai pedoman yang berasal dari dalam dirinya sendiri. Pedoman itu, mempunyai daya khusus, untuk mengenal yang baik dan yang buruk. Dalam situasi yang konkret manusia disadarkan oleh suara hati (sebagai pedoman) untuk melakukan hal yang baik demi kebahagiaan dirinya dan orang lain, dan jika tidak ia laksanakan, maka ia akan kecewa dan menyesal. ${ }^{40}$ Konsili Vatikan II dengan sangat indah mengungkapkan dalam dokumen Gaudium et Spes artikel. 16 demikian:

"Di lubuk hati nuraninya, manusia menemukan hukum, yang tidak diterimanya dari dirinya sendiri, melainkan harus ditaati. Suara hati itu selalu menyerukan kepadanya untuk mencintai dan melaksanakan apa yang baik, dan menghindari apa yang jahat. Bilamana perlu, suara itu menggemakan dalam lubuk hatinya: jalankan ini, elakkan itu sebab dalam hatinya, manusia menemukan hukum yang ditulis oleh Allah. Martabatnya ialah mematuhi hukum itu dan menurut hukum itu pula ia akan diadili."

Suara hati ialah inti manusia yang paling rahasia, sanggar sucinya; di situ ia seorang diri bersama Allah yang sapaan-Nya menggema dalam batinnya. Suara hati menjadi sanggar suci, karena pesan Allah menggema dalam hati manusia.41 Berkat suara hati, manusia mengenal hukum cinta kasih terhadap Allah dan sesama. Manusia yang setia terhadap suara hati, akan mencari kebenaran dan kebaikan (merupakan kewajiban dan tanggung jawabnya), serta akan mampu memecahkan persoalan moral dalam hidup perorangan maupun dalam kehidupan masyarakat.

Suara hati mengajak manusia untuk memberikan kesaksian tentang kebenaran itu, dalam hubungan dengan kebaikan tertinggi yaitu Allah. Bila manusia mendengarkan suara hatinya, ia dengan bijaksana dapat mendengarkan suara Allah yang berbicara di dalamnya. ${ }^{42}$ Suara hati memungkinkan manusia untuk menerima dan melaksanakan kewajiban/tanggung jawabnya dan selalu diarah untuk dilakukan,

\footnotetext{
${ }^{40}$ Bdk. Tullo Goffi-Giannino edd), Corso di Morale..., hlm. 469-473.

${ }^{41}$ KGK, no. 1776.

${ }^{42}$ KGK, no.1777.
} 
supaya dengan bantuan rahmat Allah manusia mengembangkan kebajikannya secara terus-menerus. ${ }^{43}$

Orang Kristen harus terus berjuang untuk memiliki suara hati yang jujur dalam segala hal (Ibr 13:18). Paulus berkata, "Aku terus melatih diriku untuk memiliki kesadaran agar tidak berbuat salah terhadap Allah dan manusia" (Kis 24:16). Paulus terus mengarahkan dan mengoreksi haluan hidupnya sesuai dengan kebenaran dan kebaikan (bdk. 1Kor 4:4), walaupun ia tahu/sadar bahwa dengan mengikuti suara hati, bisa mengakibatkan penganiayaan. Demikian juga Petrus memberikan nasihat yang menghibur hati, "Sebab jika karena suara hati di hadapan Allah, seseorang bertahan menanggung hal-hal yang menyedihkan hati dan menderita secara tidak adil, ini adalah hal yang diperkenan" (1Ptr 2:19). Seorang Kristen harus "mempertahankan suara hati yang baik" walaupun menghadapi tantangan dan penganiayaan (1Ptr 3:16).

\section{Setia pada Optio Fundamentalis}

Secara etimologis, istilah optio fundamentalis adalah suatu istilah Latin yang berarti Pilihan Dasar atau Putusan Dasar. Istilah ini mau mengungkapkan bahwa di dalam diri manusia terdapat suatu pilihan atau putusan yang mendasar menyangkut dirinya dan semua orang lain selama hidup. Pilihan ini muncul dari kedalaman kepribadian yang secara significant mengarahkan tujuan hidup kita atas optio itu. Pilihan itu adalah suatu komitmen personal yang harus dipertanggungjawabkan karena merupakan kualitas batin berupa keyakinan yang tumbuh dari arahan Roh Kudus, yang dipilih secara sadar dan bebas. ${ }^{44}$

Menurut Bernard Haring, pilihan dasar merupakan realisasi dari kebebasan moral. Dalam konteks ini, optio fundamentalis sepertinya dapat dipahami dalam kesatuan yang tak terbagi antara kewajiban dan tanggung jawab orang Kristen untuk mencari dan bertumbuh dalam kebenaran dan kebaikan Allah. 45 Kebebasan moral saling berelasi dengan pengetahuan dasar. Dalam relasi itu, seorang pribadi akan

${ }^{43}$ Bdk. KGK no, 1781, 1782.

${ }^{44}$ Jean-Louis Brugues, Dizionario di Morale Cattolica..., hlm. 267-268.

${ }^{45}$ Bdk. Bernard Haring, Free and Faithfull in Christ..., hlm. 182-183. 
mencapai identitasnya dan menentukan komitmennya yang total terhadap kebenaran dan kebaikan Allah sebagai sumber kebaikan. ${ }^{46}$ Dengan kata lain, pengertian ini mau mengatakan bahwa pilihan itu dibuat secara bebas.

Menurut Thomas Aquinas, pada dasarnya semua pilihan itu berakar pada dua jenis optio fundamentalis, yakni mencintai Tuhan atau mencintai ciptaan-Nya. Mencintai Tuhan berarti tunduk dan melakukan kebaikan-kebaikan (kualitas batin) dengan penuh kasih sayang dan tanggung jawab. Perihal mencintai Tuhan bukan sekedar untuk diri sendiri tetapi juga memproyeksikannya terhadap ciptaan-Nya. ${ }^{47}$

Mencintai Tuhan berarti mendedikasikan diri pada-Nya, dengan terus-menerus mencari/berada dalam kebenaran dengan melaksanakan kebaikan Allah. Kedua hal ini merupakan kewajiban dan tanggung jawab setiap orang Kristen. Melalui optio fundamentalis, Allah mengundang setiap manusia untuk menanggapi dan membalas cintaNya. Allah adalah tujuan terahkir serta kebaikan tertinggi. Oleh karena itu manusia harus menentukan sikapnya di hadapan Allah. Sikap itu direalisasikan melalui pilihan dasar ini, yang terjadi dari dalam lubuk hati pribadi manusia dan berkisar pada Allah, sebagai kebenaran dan tujuan terahkir serta Kebaikan Tertinggi. Opsi ini seharusnya tercetus dalam perbuatan susila. ${ }^{48}$

\section{Menjalani Panggilan Khusus (Optio Particularis)}

Bagaimana manusia dapat mewujudkan optio fundamentalisnya? Optio fundamentalis masih merupakan suatu pilihan umum dan mendasar pada semua manusia. Pilihan dasar ini boleh dikatakan masih abstrak dan membutuhkan perwujudan konkrit. Perwujudan optio fundamentalis hendaknya diaplikasikan melalui optio particularis. Secara etimologis, optio particularis berarti pilihan atau putusan khusus. Setiap manusia mesti membuat pilihan khusus dan konkrit untuk dirinya. hlm. 80 .

${ }^{46}$ Richard, M, Reason Informmed By Faith, (New York: Pulist Press,1989), hlm. 74 .

47 William Chang, Pengantar Teologi Moral. (Yogyakarta: Kanisius, 2001),

${ }^{48}$ Bdk. Richard M, Reason Informmed By Faith..., hlm. 78. 
Pilihan khusus ini dapat terjadi lebih dari satu, ada yang berjangka pendek dan berjangka panjang. ${ }^{49}$

Optio particularis merupakan penjabaran lebih konkrit dari optio fundamentalis. Karena itu optio particularis merupakan jalan atau cara khusus dan konkrit yang dipilih oleh setiap manusia dalam hidupnya guna mewujudkan pilihan dasarnya agar menjadi "manusia yang baik". Dalam konteks religius Kristiani, sikap martyria sungguh diharapkan dan ditekankan dalam setiap optio particularis. Melalui optio ini, orang Kristen dipanggil untuk bersaksi optio particularis (menjalani suatu bentuk hidup tertentu) guna mewujudkan atau mewartakan kebenaran dan kebaikan Allah demi kebahagiaan dirinya dan orang lain. Dengan kata lain, bersaksi melalui optio partikularis (pelbagai bentuk panggilan dan pilihan hidup, seperti menjadi imam, biarawan/ti, katekis/petugas pastoral, menjadi bapak dan ibu keluarga, dll) adalah wujud kebebasan moral (wujud kewajiban dan tanggung jawab orang Kristen).

\section{Penutup}

Orang Kristen dengan kebebasan moralnya, dianugerahkan kemampuan untuk tumbuh/matang dalam kebenaran dan kebaikan (optio fundamentalis), serta tetap setia melakukan kewajiban dan tanggung jawab. Suara hati akan selalu menyerukan agar kewajiban dan tanggung jawab tersebut dilaksanakan sehingga menjadi suatu kebajikan (dasar kebajikan), 50 dan menghasilkan yang terbaik (kehidupan moral). ${ }^{51}$ Kebajikan dan hasil yang terbaik ini, dapat dilihat/diaplikasi dalam sikap martyria (bersaksi), dan ini harus disadari oleh setiap orang Kristen sebagai suatu kewajiban dan tanggung jawab. Melalui optio partikularis, orang Kristen mempunyai

49 Bdk. Francesco Compagnoni, Giannino Piana, salvatore Privitera (a cura di), Nuova Dizionario di Teologia Morale..., hlm. 855-859.

${ }^{50}$ Bdk. KGK, no 1776.

${ }^{51}$ Bdk. KGK, no. 1828, 1829: Jiwa kasih orang-orang Kristen yang ditopang oleh kurnia-kurnia Roh Kudus. Sikap tetap manusia yang selalu mencondongkan dirinya mengikuti dorongan Roh Kudus. 
banyak peluang dan kesempatan untuk bersaksi. ${ }^{52}$ Sudahkah aku memanfaatkan segala kemungkinan dan kesempatan yang ada? Bersaksi (tetaplah bersaksi) dalam kebenaran dan kebaikan Allah demi kemuliaanNya.

$$
===0000===
$$

\section{DAFTAR PUSTAKA}

\section{Dokumen-dokumen Resmi Gereja}

Katekismus Gereja Katolik. Diterjemahkan oleh P. Herman Embuiru. Ende: Flores Arnoldus, 1995.

Dokumen Konsili Vatikan II. Diterjemahkan oleh R. Hardawiryana. Jakarta: Dokumentasi dan Penerangan KWI-Obor, 1993.

\section{Buku-buku Pendukung}

Beyruther, E. New International Dictionary of New Testament Teology 2. Abridged Edition, 2000.

Brugues, Jean-Louis. Dizionario di Morale Cattolica. Bologna: PDUL Edizione Studio Domenicano, 1991.

Di Berardino, Angelo (diretto da). Dizionario Patristico e Diantichita Cristiane. Casale Monferrato: Casa Editrice Marietti, 1983.

Departemen Pendidikan Nasional. Kamus Besar Bahasa Indonesia Pusat Bahasa (edisi keempat). Jakarta : Penerbit PT Gramedia Pustaka Utama, 2012

Chang, William. Pengantar Teologi Moral. Yogyakarta: Kanisius, 2001.

${ }^{52}$ Kewajiban bersaksi dapat dilakukan melalui pendidikan, pekerjaan sosial, film, lagu, sinteron, budaya, melalui traktat, email, facebook, twiters, melalui khotbah, seminar, bakti sosial, pertolongan darurat, dll. 
Haring, Bernard. Free and faitfull in Christ, Vol. I. London: Slough, Midddlegreen, St. Paul Publications, 1979.

. Kebebasan Anak Allah (judul asli: The Liberty of the Childer of

God). Diterjemahkan oleh L. Soesila. Yogyakarta: Kanisius, 1973. . The Law of Christ: Moral Theology for Priests and Laity. Vol. III.

Cord: The Mercier Press, 1959.

Henry, Carl Ferdinand Howard. Christian Personal Ethics. Grand Rapids: William B. Eerdmans, 1957.

Gatti, Guido. Manuale di Teologia Morale. Leumann-Torino: Editrice Elledice, 2001.

Giannino, Tullo Goffi (edd). Corso di Morale, Brescia: Editrice Queriniana, 1989.

MacIntyre, Alasdair. After Virtue: A Study in Moral Theory, Second Edition. Notre Dame: University of Notre Dame Press, 1984.

Marco Vironda, Flavio Dalla Vecchia, Giuseppe Segalla, (a cura di). Nuovo Grande Commentario Biblico (Edisizione Italiana). Brescia: Editrice Queriniana, 1997.

Richard, M. Reason Informmed By Faith. New York: Pulist Press, 1989.

Suseno, Franz Magnis. ETIKA DASAR: Masalah-masalah Pokok Filsafat Moral. Yogyakarta: Penerbit Kanisius, 1987.

Salvatore Privitera, Giannino Piana, Francesco Compagnoni(a cura di). Nuova Dizionario di Teologia Morale. Milano: Edizione San Paolo, 1990. 